\title{
Notatki z historii natryskiwania termicznego
}

\section{Notes of thermal spraying history}

\section{Streszczenie}

Zaprezentowano pierwsze technologie natryskiwania termicznego opracowane w czasach wprowadzenia technologii spawalniczych oraz pierwsze technologie natryskiwania, które zostały zastosowane w praktyce. Przedstawiono pierwsze zastosowania natryskiwania oraz ujawniono słabe strony każdej z metod.

Omówiono także pokrótce początki nowocześniejszych technologii natryskiwania: plazmowego, HVOF oraz gazodynamicznego.
Abstract

First technologies of thermal spraying, developed in early years of welding and early technologies which have found practical use were presented. First applications of thermal spraying and weak points of each method were described.

Roots of more modern thermal spraying technologies like plasma spraying, HVOF spraying and cold spraying were briefly described too.

\section{Wstęp}

Jednym z najstarszych sposobów nanoszenia warstw w celu modyfikacji właściwości przedmiotów było malowanie umożliwiające np. zmianę koloru i zabezpieczenie przed korozją powierzchni, łączące walory estetyczne z praktycznymi. Z drugiej strony, najstarszym i przez wiele lat jedynym sposobem wytwarzania warstw metalicznych było platerowanie. W tym procesie na metalowe podłoże nanoszono cienką warstwę innego metalu, zwykle o wysokiej plastyczności, w fazie stałej, np. złota na miedź. Technologia wytwarzania powłok galwanicznych pojawiła się dopiero w połowie XIX w.

\section{Natryskiwanie płomieniowe}

Pierwsza spawalnicza technologia nanoszenia warstw została opatentowana przez Szwajcara Maxa Ulricha Schoopa w 1909 r. Pomysł zrodził się podobno z uważnej obserwacji otoczenia. Schoop zwrócił uwagę na mur-kulochwyt sportowej strzelnicy pod Paryżem, gdzie intensywnie strzelano ołowianymi pociskami. Zauważył, że pociski silnie deformują się, uderzając w mur i wklinowują w jego nierówności, a gdy trafią na wcześniej wbity w ścianę pocisk - łączą się z nim

Dr inż. Tomasz Szulc - Politechnika Wrocławska. i nie dają później rozdzielić. Pomogła mu także niewątpliwie znajomość procesu rozpylania ciekłego ołowiu strumieniem powietrza, co praktykowano m.in. w zarządzanej przez jego brata fabryce akumulatorów Oerlikona. Urządzenia do rozpylania ołowiu opatentowano w Niemczech w 1882 r. (patent DRP 24460), a w wersji udoskonalonej z gorącą parą wodną jako medium rozpylającym - w 1892 r. (patent nr 86983).

Patent Schoopa, wydany przez niemiecki Kaiserliches Patentamt, obowiązywał od 28.04.1909 r. i dotyczył „Verfahren zum Herstellen dichter metallischer Ueberzuege", czyli metody wytwarzania zwartych pokryć metalicznych [1]. Podobne patenty, Schoop uzy-

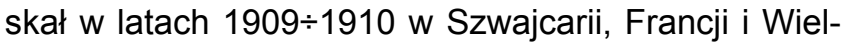
kiej Brytanii, a potem, w ciągu sześciu lat, był stroną w 45 sprawach sądowych, dotyczących praw do patentu.

Pierwsze urządzenie Schoopa było stacjonarne. Medium rozpylającym był sprężony dwutlenek węgla ogrzewany specjalnym palnikiem. Służył on również do wypierania ciekłego metalu z tygla. Urządzenie, ze względu na bardzo ograniczony zakres zastosowań, można uznać za instalację eksperymentalną. Do praktycznego użycia lepiej nadawał się pistolet, w którym jako materiał dodatkowy Schoop zastosował drut, a jako źródło ciepła płomień acetylenowo-tlenowy. Medium rozpędzającym krople stopionego metalu było sprężone powietrze. Ten projekt powstał w 1912 r., a pierwsze urządzenia seryjne wyprodukowano już trzy lata później. W 1921 r. Schoop skonstruował pistolet zasilany proszkiem, który nazwał PG (powder-gun). 
Co ciekawe, urządzenie do natryskiwania sproszkowanym metalem opatentowano w USA już w 1900 r. [2], ale służyło ono do natryskiwania zimnym materiałem dodatkowym, a więc nie należy do kategorii sprzętu do natryskiwania termicznego ani sprzętu spawalniczego.

W 1917 r. opublikowano w Niemczech pierwsze opracowanie na temat natryskiwania termicznego [3]. Parę lat później kilku autorów, niezależnie od siebie, próbowało stworzyć teoretyczne podstawy procesu, a co najmniej wyjaśnić mechanizm tworzenia warstw

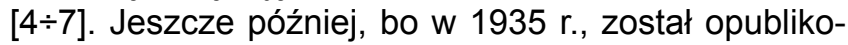
wany w Austrii pierwszy poradnik natryskiwania [8]. Przez pierwsze dwadzieścia lat od opatentowania technologii stosowano ją niemal wyłącznie do celów ozdobnych (pokrywanie powłokami z metali nieżelaznych wyrobów stalowych, kamiennych i gipsowych) oraz nanoszenia cynkowych i aluminiowych powłok antykorozyjnych na konstrukcje stalowe [9]. Aplikacje regeneracyjne były dużo rzadsze, mimo marketingowych działań Schoopa [10]. Dopiero pod koniec lat 30. XX w. zaczęto stosować natryskiwanie do nanoszenia powłok ze stopów łożyskowych [11].

W Polsce natryskiwanie budziło zaskakująco duże zainteresowanie. W 1923 r. została założona firma Metalizator - filia Metallizator Geselschaft Berlin Schoopa, która działała do 1932 r. i współpracowała m.in. ze stocznią rzeczną w Modlinie, gdzie cynkowano kadłuby łodzi motorowych [12]. W 1934 r. (a więc przed opublikowaniem podręcznika Schoopa) w kalendarzu spawalniczym fabryki Perun na następny rok opublikowano obszerne opracowanie - poradnik dotyczący natryskiwania [13]. Do zagadnień wrócono po wojnie, a pierwszą dużą publikacją na ten temat był podręcznik Kowalewskiego z 1957 r. [14]. Niezależnie od tego kilkanaście lat później w najbardziej wówczas miarodajnej publikacji w branży, czyli Poradniku Spawalniczym, nie napisano o natryskiwaniu ani słowa [15].

W Instytucie Mechaniki Precyzyjnej w Warszawie na początku lat 60. ub.w. opracowano pistolet do płomieniowego natryskiwania drutem Metal-63A. a nieco wcześniej do natryskiwania proszkami typu GPM-L2 i PP-1. Pistolet proszkowy PM-12A produkowała także fabryka Perun. Szacowano, że w 1967 r. w Polsce było ok. 150 stanowisk do metalizacji [12].

\section{Natryskiwanie łukowe}

Kolejna technologia - natryskiwanie łukowe ma również związek z Schoopem. Opatentowała ją w 1918 r. obywatelka Szwajcarii Frieda Neininger, która w 1929 r. została żoną Schoopa [16, 17]. W literaturze podaje się jednak, że pierwszą głowicę łukową skonstruował osobiście Schoop w 1914 [12] lub 1917 r. [11]. W przypadku tej metody źródłem ciepła był łuk elektryczny, jarzący się między końcówkami dwóch drutów, będących materiałem dodatkowym i rozwijanych za pomocą mechanicznego napędu ze szpul. Łuk miał charakter zwarciowy, ale częstotliwość

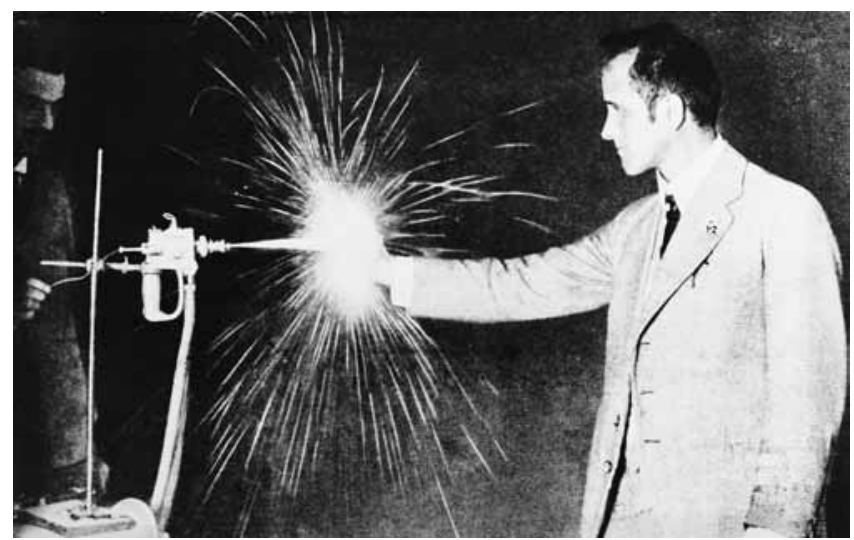

Rys. 1. Schoop podczas natryskiwania demonstruje, do jak niskiej temperatury nagrzewa się podłoże [10]

Fig. 1. Schoop shows how low the temperature of the base material during thermal spraying is [10]

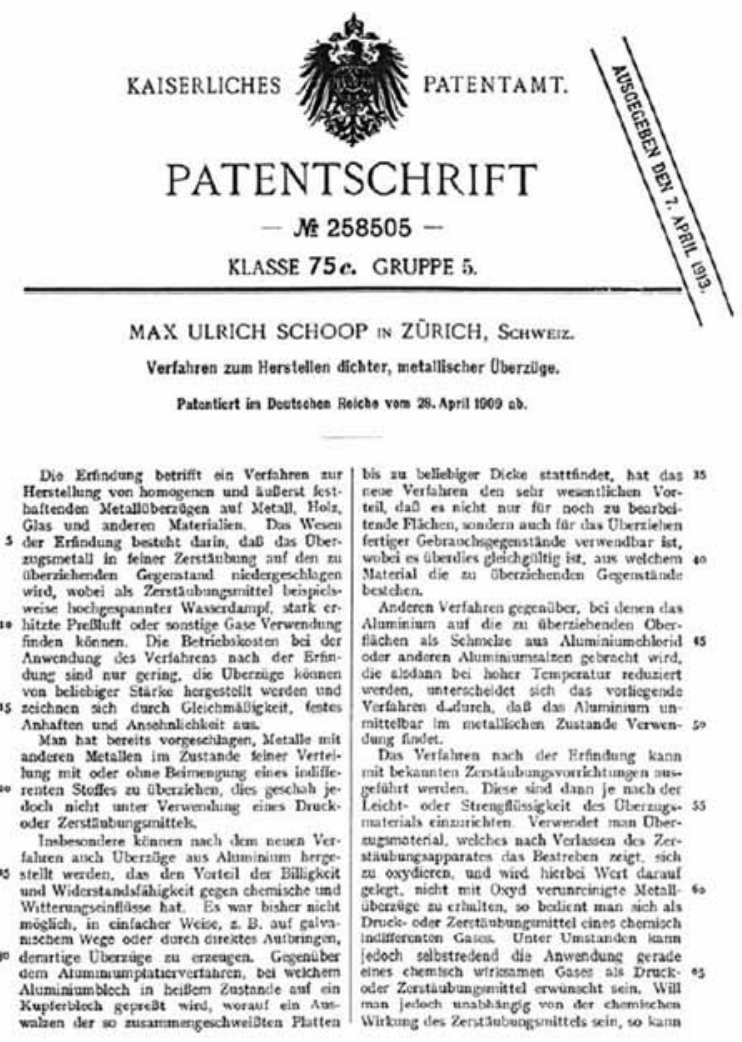

Rys. 2. Pierwsza strona patentu Schoopa [1]

Fig. 2. First page of the Schoop's patent [1]

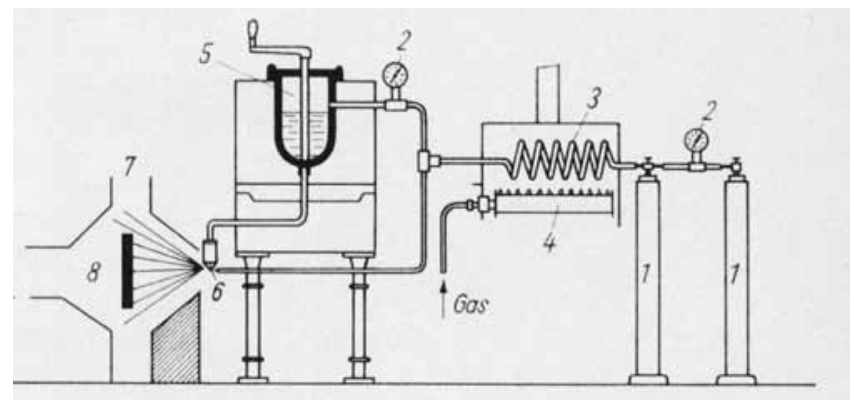

Rys. 3. Schemat urządzenia Schoopa: 1 - butla $\mathrm{CO}_{2}, 2$ - reduktor, 3 - nagrzewnica gazu, 4 - palnik, 5 - tygiel z ciekłym metalem, 6 -dysze, 7 - komin, 8 - przedmiot pokrywany [29]

Fig. 3. Construction of the Schoop's device: $1-\mathrm{CO}_{2}$ cylinder, $2-$ gas regulator, 3- gas heater, 4 - torch, 5 - crucible with liquid metal, 6 - nozzles, 7 - stack, 8 - covered detail [29] 
zwarć była tak duża, że proces można uznać za ciągły. Dokładnie w osi punktu stapiania znajdowała się dysza, doprowadzająca sprężone powietrze, które rozpylało stopiony metal i nadawało mu odpowiednią energię kinetyczną. Niewątpliwe zalety tej metody to co najmniej dwukrotnie wyższa temperatura topienia materiału dodatkowego, niż w przypadku natryskiwania płomieniowego, kilkakrotnie większa wydajność i co najmniej teoretyczna możliwość uniknięcia utleniania stopionego materiału dodatkowego (w przypadku natryskiwania gazami obojętnymi w atmosferze

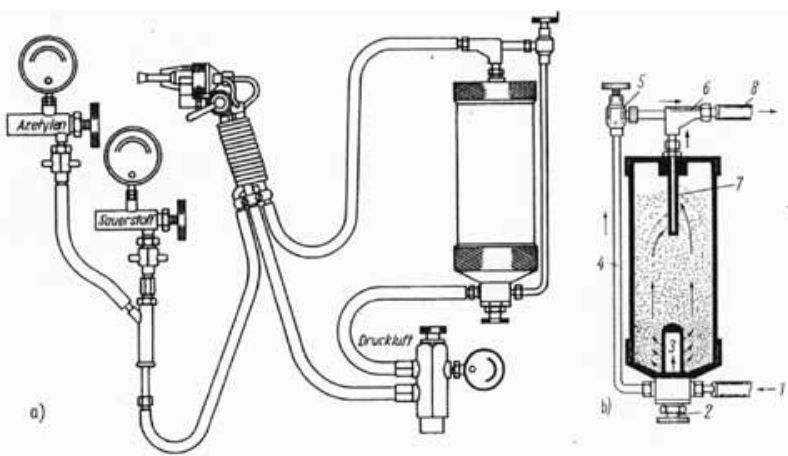

Rys. 4. Schemat pistoletu Schoopa do natryskiwania proszkiem [29] Fig. 4. Schoop's powder spray gun [29]

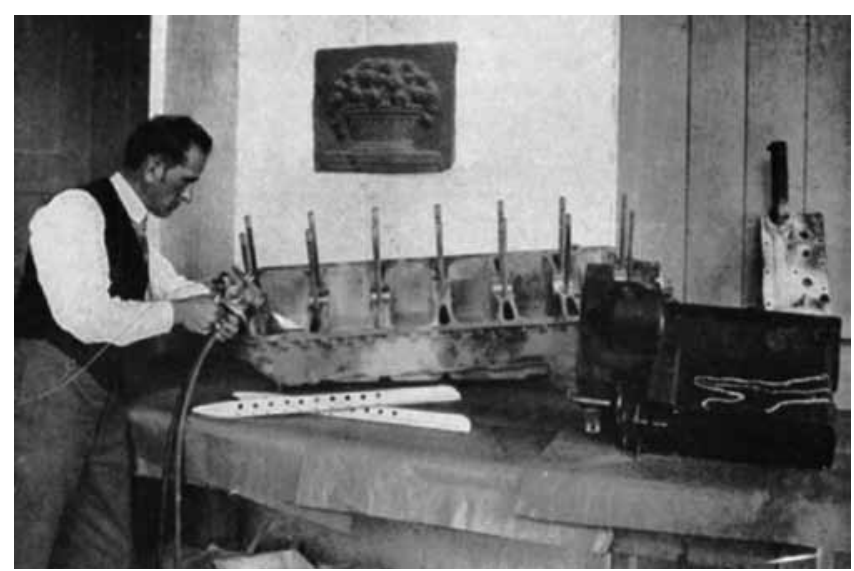

Rys. 5. Schoop demonstruje możliwość regeneracji bloku silnika lotniczego [17]

Fig. 5. Schoop demonstrates the possibility to repair the aircraft engine [17]

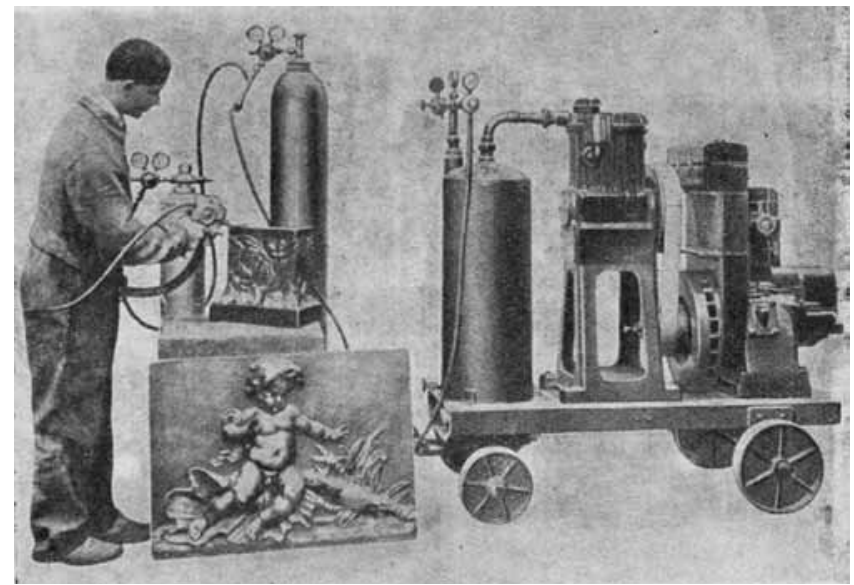

Rys. 6. Mobilne stanowisko do natryskiwania z końca lat 20. ub.w [13]

Fig. 6. Mobile spraying equipment set. Late twenties of the last century [13] ochronnej). Wady metody to bardziej skomplikowane urządzenie, niemożność nanoszenia warstw z materiałów ceramicznych (nie przewodzą prądu) oraz trudności z produkcją materiałów cermetalowych w postaci drutów rdzeniowych.

Pierwsze urządzenie do natryskiwania łukowego zostało skonstruowane w Szwajcarii w 1918 r., a w Polsce pierwsze takie urządzenie, oznaczone EPM-ŁJ2, powstało w Instytucie Mechaniki Precyzyjnej w 1956 r. W 1958 r. wyprodukowano tam niewielką partię pistoletów PE-1, a w 1962 r. PE-2. Na większą skalę produkowano w IMP-ie maszynowe (stacjonarne) głowice BMG-76.

\section{Natryskiwanie detonacyjne}

Obiecującą odmianą natryskiwania termicznego stało się natryskiwanie detonacyjne. Jego idea zrodziła się z konstatacji Schoopa, że decydujący wpływ na właściwości nanoszonych warstw ma energia kinetyczna ziaren materiału dodatkowego. Oznacza to, że najważniejszą zmienną procesu jest prędkość ziaren i, pośrednio, prędkość strumienia gazu transportującego. Największe szanse na radykalne zwiększenie tej prędkości dawało wykorzystanie do rozpędzania i transportu ziaren w stronę materiału pokrywanego fali uderzeniowej detonacji w środowisku gazowym. Wiadomo, że prędkość czoła takiej fali może wynosić 1500 do 8000 m/s, co stanowi kolosalną różnicę w porównaniu z prędkościami uzyskiwanymi przy wykorzystaniu strumienia sprężonego gazu [18]. Znana i sprawdzona była również konstrukcja urządzeń, wykorzystujących w praktyce energię wybuchu do nadawania energii ciałom stałym - była to broń palna, znana od ok. 600 r. p.n.e. [19]. Nic więc dziwnego, że konstrukcja urządzeń do natryskiwania detonacyjnego bardzo przypomina właśnie broń palną - do relatywnie długiej lufy, zapewniającej nadanie materiałowi dodatkowemu właściwego kierunku i jego przyspieszanie przez odpowiednio długi czas, jest wdmuchiwany sproszkowany materiał dodatkowy oraz mieszanka gazu palnego i utleniacza. Zapłon, zwykle elektryczny, wywołuje eksplozję, powstanie fali uderzeniowej, która porywa ze sobą ziarna materiału dodatkowego i nadaje im energię kinetyczną. Z czasem stwierdzono, że mimo wysokiej temperatury eksplozji, ziarna nagrzewają się w niewielkim stopniu, co jest skutkiem bardzo krótkiego czasu ich kontaktu ze źródłem ciepła. Rozpędzają się natomiast do prędkości, przekraczającej co najmniej dwukrotnie prędkość dźwięku.

Pierwszy patent dotyczący natryskiwania detonacyjnego zgłosiła w marcu 1952 r. amerykańska firma Union Carbide pod nazwą "Method and apparatus utilizing detonation waves for spraying and other purposes" (Metoda i urządzenie wykorzystujące fale detonacyjne do natryskiwania i innych celów) [20]. W opisie patentowym nie było jednak wielu szczegółów, co oznacza, że zgłoszono go na wczesnym etapie prac, ale za to 
pozwoliło to później innym specjalistom i instytucjom zgłaszać swoje patenty w tej dziedzinie. Od połowy lat 60. ub.w najaktywniej działali w tej dziedzinie uczeni radzieccy: A. Zwieriew [21], A. Bondarenko, A. Andruszak, A. Astachow i in. [22, 23].

Szybko okazało się, że natryskiwanie detonacyjne ma oprócz istotnych zalet również poważne wady. Zaletami były: prostota konstrukcji urządzenia i wysokie prędkości cząstek materiału nanoszonego. Pierwsze urządzenie firmy Union Carbide, opracowane w jej laboratorium Speedway Labs w Indianapolis przez R. Poormana, H. Sargenta i G. Hawleya, znane pod zarejestrowaną nazwą D-gun, czyli detonation gun (działo detonacyjne) miało „lufę” o długości ok. $1 \mathrm{~m}$ i kalibrze ok. $25 \mathrm{~mm}$. Było zasilane mieszanką $\mathrm{C}_{2} \mathrm{H}_{2}+\mathrm{O}_{2}$, a elektryczny zapłon generował detonacje $z$ częstotliwością od 4 do $8 \mathrm{~Hz}$. Ziarna proszku osiągały prędkość ok. $750 \mathrm{~m} / \mathrm{s}$, co w zupełności wystarczało do tworzenia spoistych warstw WC na powierzchniach narzędzi skrawających, głównie stosowanych dla potrzeb przemysłu wydobywczego.

Podstawową wadą technologii był towarzyszący natryskiwaniu hałas, który przekraczał $145 \mathrm{~dB}$. Oznaczało to potrzebę wydzielenia procesu natryskiwania $z$ ciągu technologicznego i przeniesienia go do izolowanych pomieszczeń lub na odległe stanowiska poligonowe, co komplikowało proces produkcyjny. Drugą wadą był cykliczny proces nanoszenia materiału na podłoże, który skutkował powstawaniem warstw o nierównej grubości, gdyż każdy „strzał” powodował powstanie okrągłego obszaru pokrytego warstwą o gaussowskim rozkładzie grubości - wyraźnie największa była w centrum obszaru. Sposobem na zmniejszenie negatywnego wpływu drugiej ze wspomnianych wad było zwiększenie częstotliwości detonacji, do nawet ponad $100 \mathrm{~Hz}$. Sposobem na częściowe zniwelowanie obu wad jest automatyzacja procesu natryskiwania, czyli stworzenie urządzeń, które przemieszczałyby pracującą głowicę zgodnie z zadaną trajektorią i prędkością (dzięki czemu można byłoby precyzyjnie zsynchronizować ruch postępowy z częstotliwością wystrzeliwania kolejnych porcji proszku i uzyskać odpowiednio nakładające się na siebie obszary pokrywane, a więc i bardziej równomierną grubość). Brak konieczności bezpośredniego udziału operatora w procesie natryskiwania zmniejszył uciążliwość hałasu - proces mógł się odbywać w całkowicie izolowanych pomieszczeniach. Rezultatem zastosowania tych rozwiązań był jednak także znaczący wzrost kosztów instalacji i jej eksploatacji, a to z kolei wpłynęło na spadek zainteresowania technologią natryskiwania detonacyjnego. W Polsce prace nad nią prowadzono od lat 60. ub.w. w Wojskowej Akademii Technicznej w Warszawie, ale zainteresowanie ze strony przemysłu było niewielkie.

\section{Natryskiwanie plazmowe}

Drugą z metod natryskiwania, z którą nie jest kojarzony Schoop, stało się natryskiwanie plazmowe. Sam

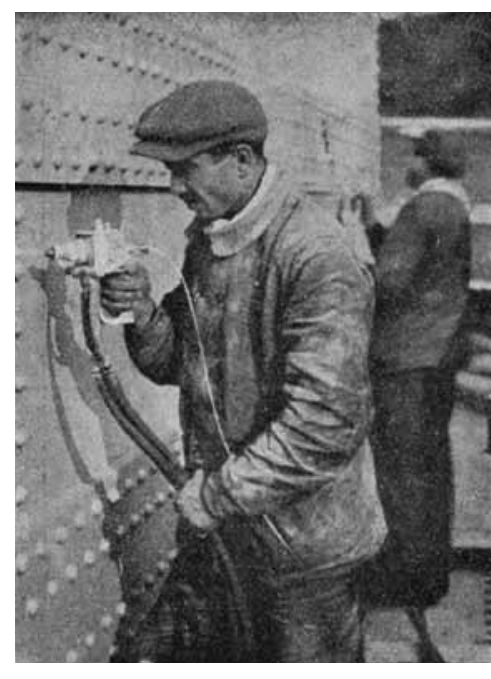

Rys. 7. Cynkowanie wrót śluzy Vauban koło Strassburga [30]

Fig. 7. Protecting of the Vauban canal lock door by flame sprayed zinc layer [30]

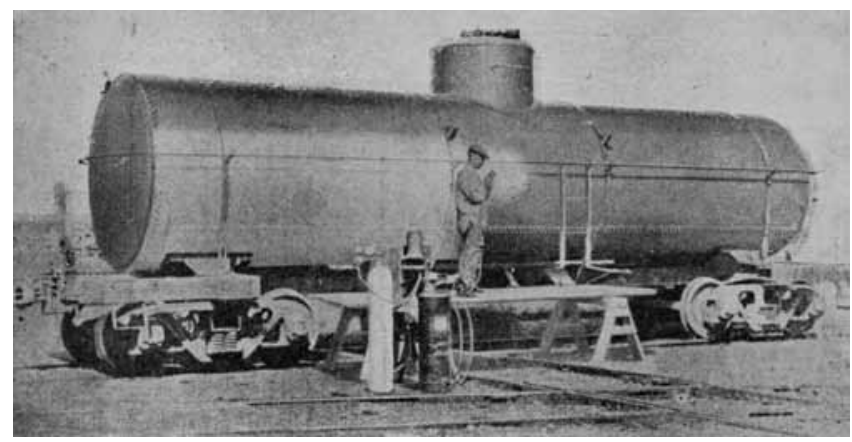

Rys. 8. Cynkowanie cysterny kolejowej [13]

Fig. 8. Spaying of the zinc layer on the railroad tank [13]

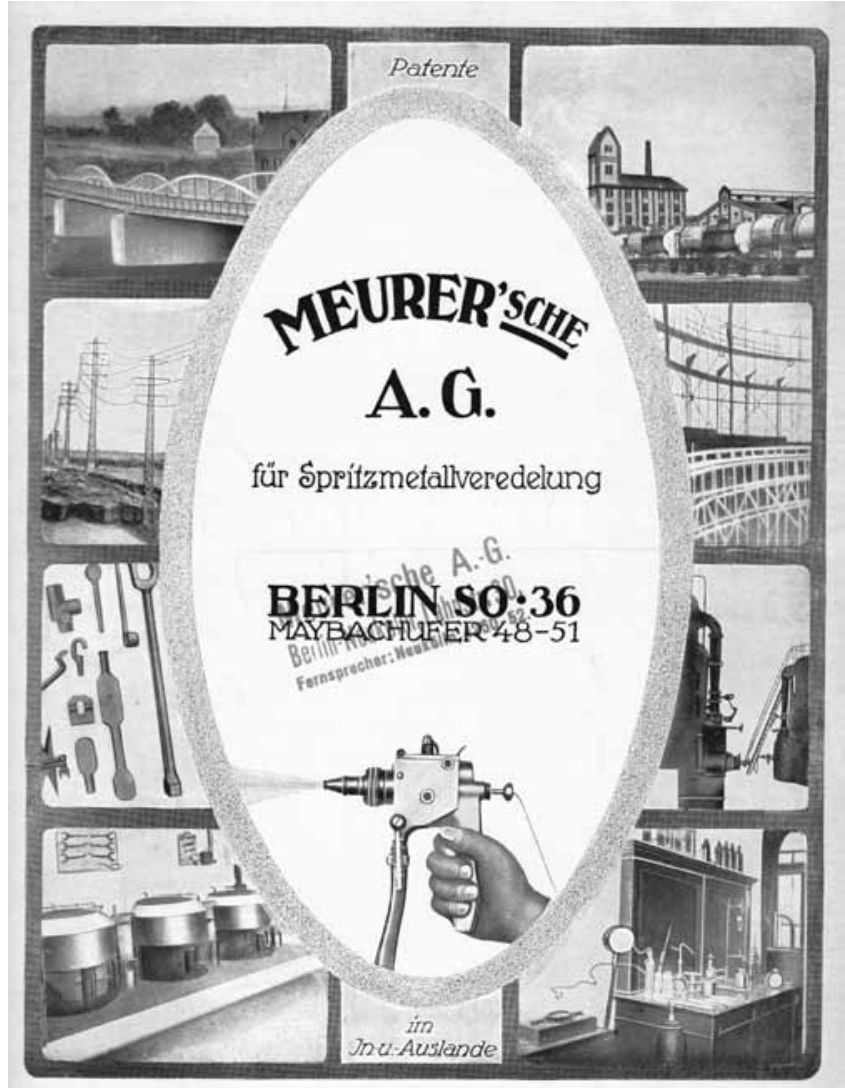

Rys. 9. Okładka prospektu niemieckiej firmy Meurer’sche A.G. füer Spritzmetallveredelung ok $1925 \mathrm{r}$.

Fig. 9. First page of the offer of the German company Meurer'sche concerning thermal spraying, about 1925 [30] 
termin plazma pochodzi również od uczonego, laureata nagrody Nobla, który miał także osiągnięcia w dziedzinie spawalnictwa - I. Langmuira (wynalazcy metody ArcAtom), który użył go po raz pierwszy w 1928 r. w odniesieniu do zjonizowanego gazu. Pierwszy patent, opisujący metodę natryskiwania plazmowego, pochodzi z 1962 r. i należy do R.M. Gage'a, O.H. Nestora i D.M. Yenniego z firmy Union Carbide. Patent ma numer US 3016447 i opisuje „Collimated electric arc powder deposition proces”, czyli „Proces nakładania

\section{Cynowanie.}

1) Opiaskować starannie powierzchnie do metalizowania.

2) Metalizować natychmiast po oczyszczeniu, nakiadając warstwe grub. $0.2 \mathrm{~mm}$ (5 przejsć pistoletu).

3) Natychmiast po nametalizowaniu należy zwilżyć powierzchnię zapomoca płynu utrwalającego, dostarczanego przez Sp. Akc. „Perun".

Do przedmiotów wystawionych na działanie rozcieńczonych kwasów organicznych w temperaturze zwykłej stosuje się płyn "Tynomet".

Zwilżanie powierzchni tym płynem powinno się wykonywać zapomoca płaskiego pędzla, unikając nadmiaru płynu. Przedmiot należy pozostawić do wyschniecia na cała dobe

Przedmioty $w$ ten sposób przygotowane sa odporne na działanie kwasów organicznych i znajdują szerokie zastosowanie w przemyśle spoźywczym.

Do przedmiotów wystawionych na działanie wyższych temperatur i kwasów stężonych - należy stosować płyn "Permet".

\section{Aluminjowanie.}

1) Opiaskować starannie powierzchnię przedmiotu.

2) Przystapić do metalizowania natychmiast po opiaskowaniu, starając się uregulować płomień w taki sposób, aby był moźliwie neutralny (nieutleniający).

Nałożyć warstwę grub. $0.16 \mathrm{~mm}$ co odpowiada 4-krotnemu przejściu pistoletu nad powierzchnia.

3) Natychmiast po metalizowaniu zanurzyć przedmiot w specjalnym płynie do utrwalania, wyrabianym przez Sp. Akc. „Perun”. przy przedmiotach większych należy rozprowadzić płyn po powierzchni nametalizowanej zapomoca pędzla lub gabki.

\section{4}

Rys. 10. Fragment pierwszego polskiego poradnika natryskiwania [13]

Fig. 10. Pages of the first Polish thermal spraying handbook [13]

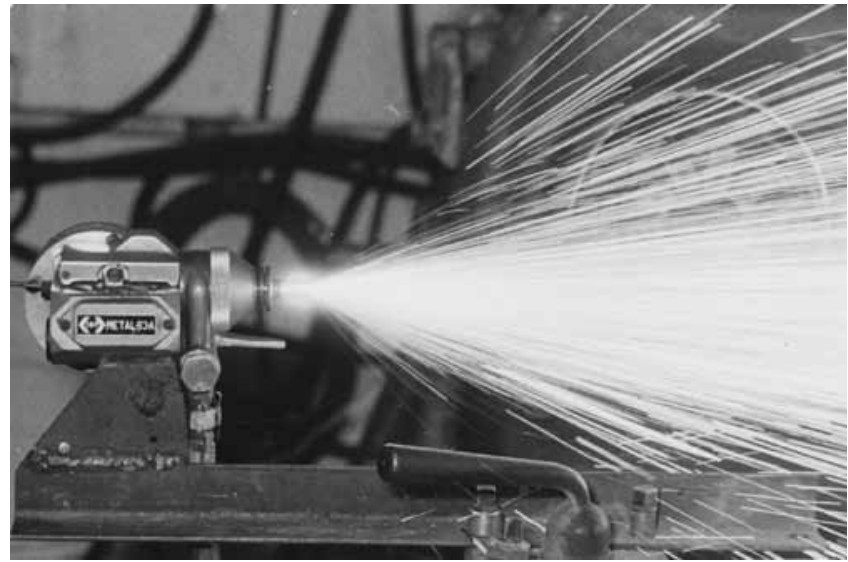

Rys. 11. Pistolet Metal $63 \mathrm{~A}$ podczas natryskiwania aluminku niklu. Fot. T. Szulc

Fig. 11. Metal 63A spray gun at the nickel aluminide spraying. Photo T. Szulc (warstw z) proszku za pomoca skoncentrowanego łuku elektrycznego". Kolejne, liczne patenty w tej dziedzinie zostały opublikowane w kolejnych latach (np. patent R. Johnsona nr US 3179783 z 1965 r. dotyczący nanoszenia warstw plazmą z łukiem zależnym i in.). Natryskiwanie plazmowe szybko zyskało popularność za sprawą swej uniwersalności - wysoka temperatura plazmy pozwala na stopienie dowolnego materiału dodatkowego i zapewnia relatywnie dużą przyczepność warstw, będącą między innymi skutkiem dużej

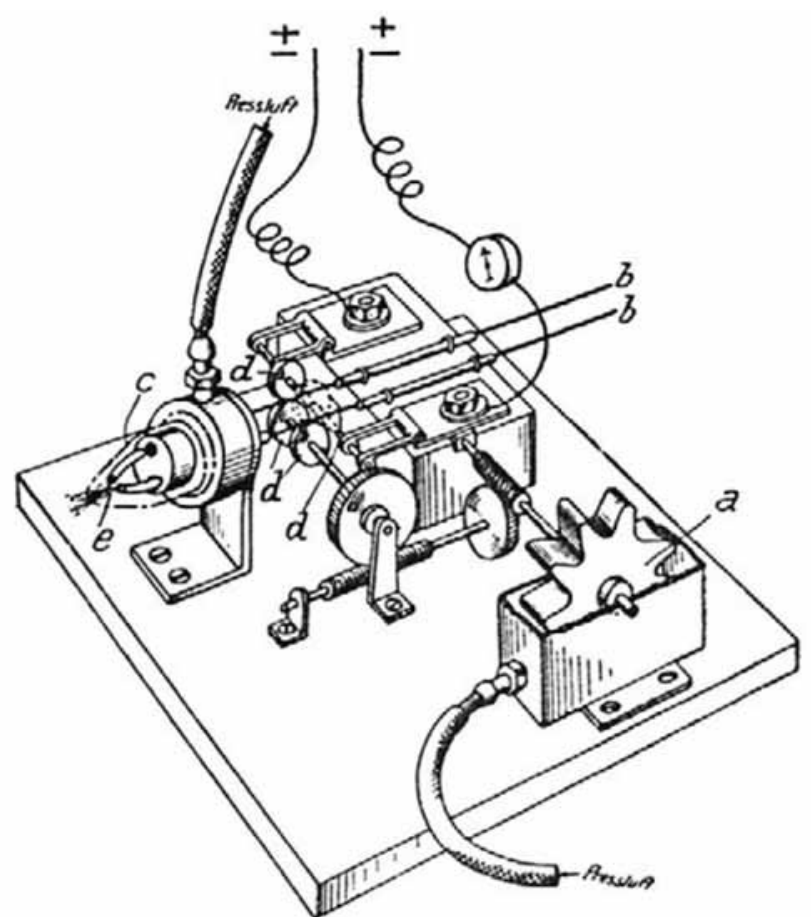

Rys. 12. Schemat głowicy do natryskiwania łukowego z opisu patentowego [16]

Fig. 12. Drawing of the arc spraying head taken from the patent [16]

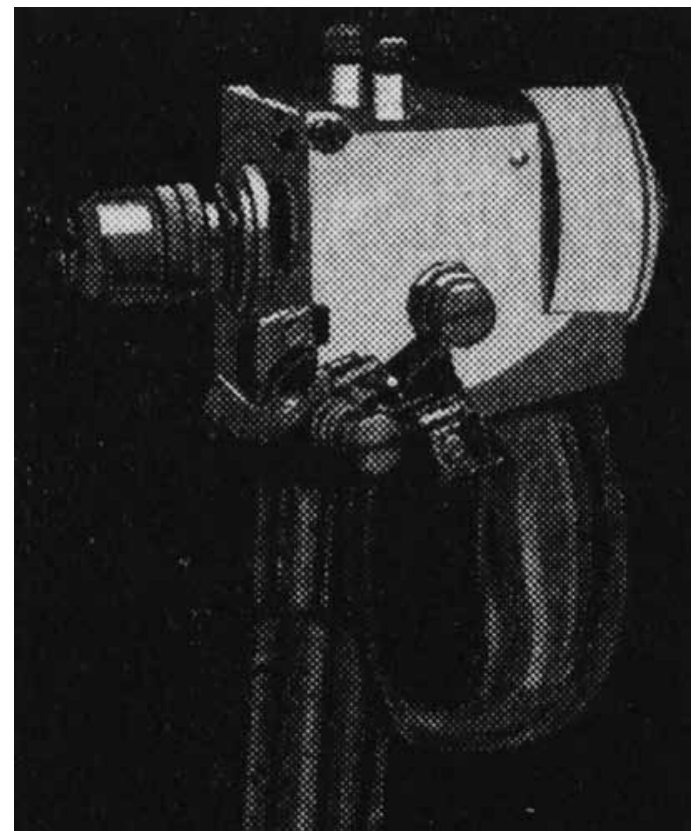

Rys. 13. Pierwsza seryjna głowica do natryskiwania łukowego [29] Fig. 13. First series arc spraying gun [29] 
prędkości, do jakiej rozpędzają się ziarna materiału dodatkowego w naddźwiękowym strumieniu plazmy. Przyczyną, dla której plazmotrony nie wyparły innych technologii nanoszenia, jest niewątpliwie ich nadzwyczaj wysoka cena, niewielka wydajność natryskiwania, wysokie wymagania dotyczące kwalifikacji obsługi oraz hałaśliwość procesu.

W Polsce konstruowaniem plazmotronów do natryskiwania zajmował się Instytut Energii Atomowej, a większość powstałych tam konstrukcji wiąże się z osobą dr. inż. M. Mikosia, entuzjasty i znawcy tych urządzeń. Pierwszym produkowanym seryjnie urządzeniem tego typu był plazmotron Plancer PN-120 o mocy 40 kW. W 1987 r. został opatentowany [24] polski plazmotron prądu stałego.

\section{Natryskiwanie metodą Jet}

Interesującą i udaną próbą połączenia zalet i wyeliminowania wad natryskiwania płomieniowego i detonacyjnego było opracowanie technologii natryskiwania HVOF - high velocity oxygen fuel (natryskiwanie płomieniowe o dużej prędkości). Amerykański patent na nią wydano już w 1958 r. G.H. Smithowi, J.F. Peltonowi i R.C. Eschenbachowi [25], ale nie doprowadzili oni do praktycznej realizacji swego pomysłu, zakładającego wykorzystanie materiału dodatkowego w postaci proszku lub drutu i wodne chłodzenie wydłużonej dyszy urządzenia. Dlatego za twórcę metody jest uważany J. Browning, znany amerykański konstruktor urządzeń plazmowych, który pod nazwą JetKote wdrożył w 1982 r. urządzenie, sprzedawane przez firmę Deloro Stellite z Indiany (USA), znane $z$ pionierskich prac $w$ dziedzinie napawania, opisana w Przeglądzie Spawalnictwa 9/2011 [26]. Kilka lat później podobne urządzenia zaczęły produkować inne firmy, np. UTP (Uni Spray Jet z 1985 r.). Urządzenie konstrukcyjnie jest niemal identyczne z głowicą do natryskiwania płomieniowego proszkiem, ale jego dysza ma specjalną konstrukcję, dzięki której strumień spalającej się mieszanki gazowej rozpędza się do prędkości naddźwiękowej. Proces ma przebieg quasi-ciągły,

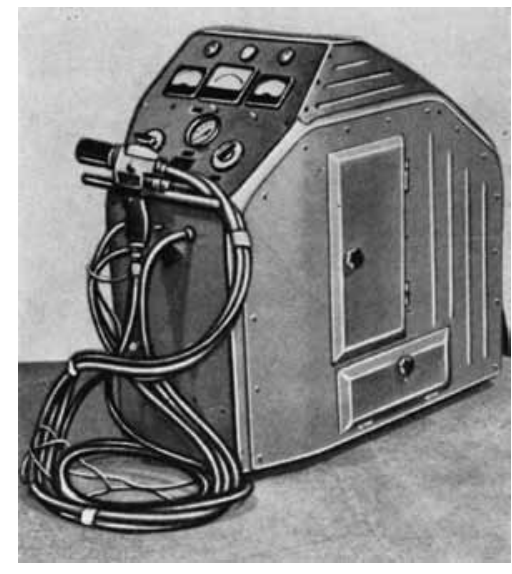

Rys. 14. Polskie urządzenie do metalizacji łukowej PE-2 - szafa sterująca mieściła wewnątrz szpule $z$ drutem [12]

Fig. 14. Polish arc spraying device PE-2 - the housing contains control panel, power source and wire feeding [21]

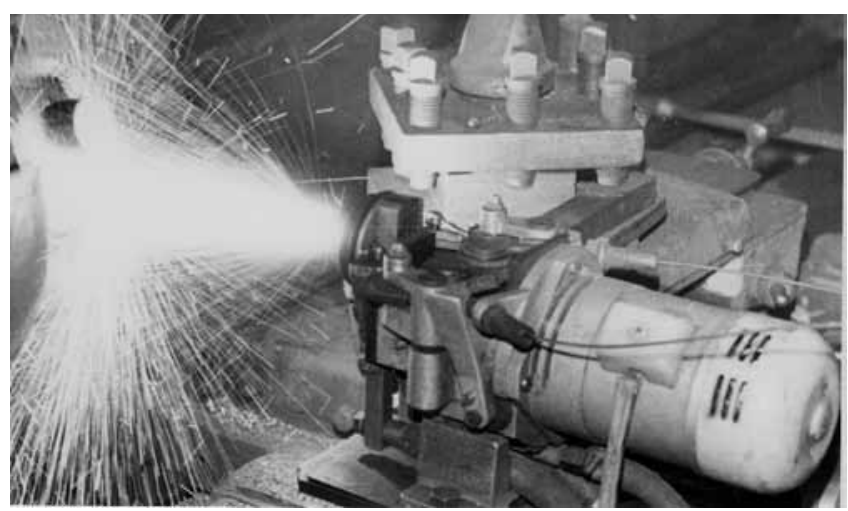

Rys. 15. Głowica do natryskiwania łukowego BMG-76. Fot. T. Szulc Fig. 15. Arc spraying head BMG-76. Photo T. Szulc
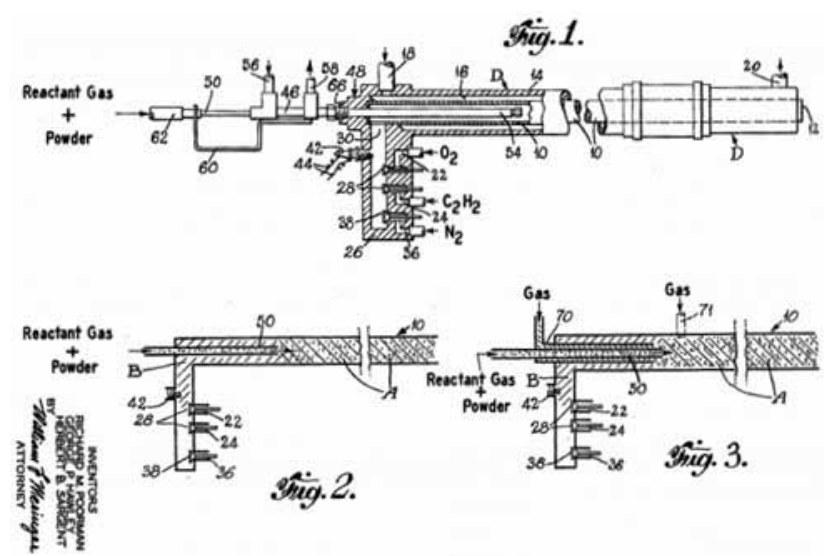

Rys. 16. Patentowy rysunek urządzenia do natryskiwania detonacyjnego [22]

Fig. 16. Detonation spraying device - drawing taken from patent [22]

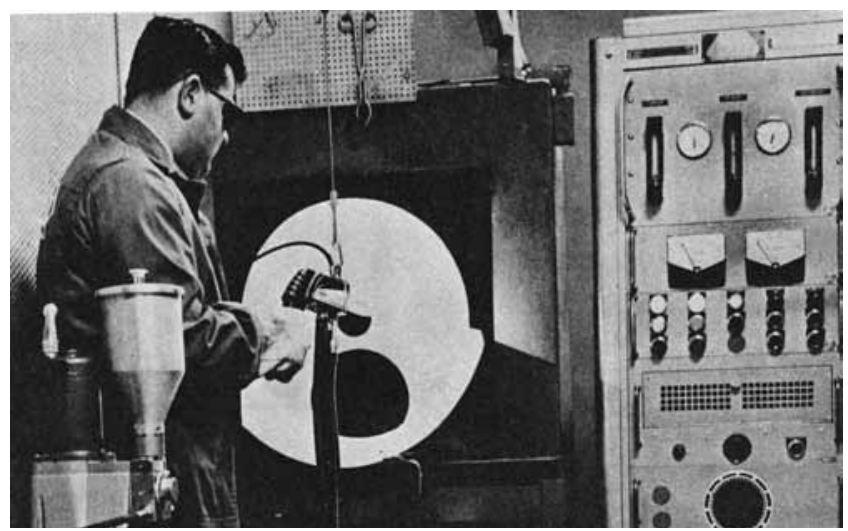

Rys. 17. Stanowisko do metalizacji plazmowej firmy Metco z początku lat 60. ub.w. [9]

Fig. 17. Stand for plasma spraying made by US company Metco in early sixties of the last century [9]

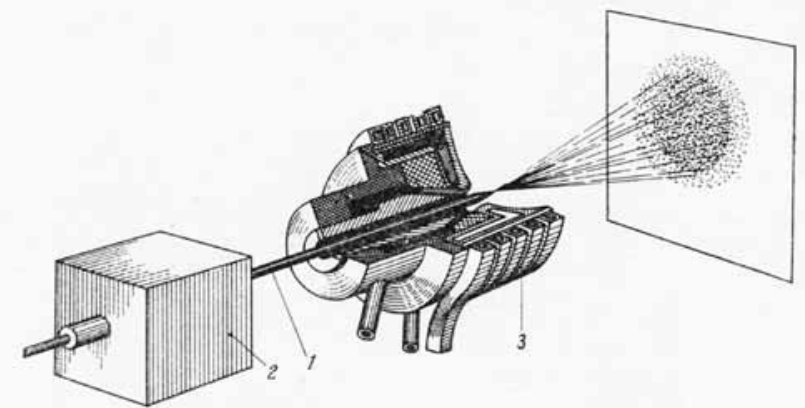

Rys. 18. Schemat głowicy do natryskiwania zasilanej prądem wysokiej częstotliwości [29]

Fig. 18. The drawing of the high frequency current spraying device [29] 


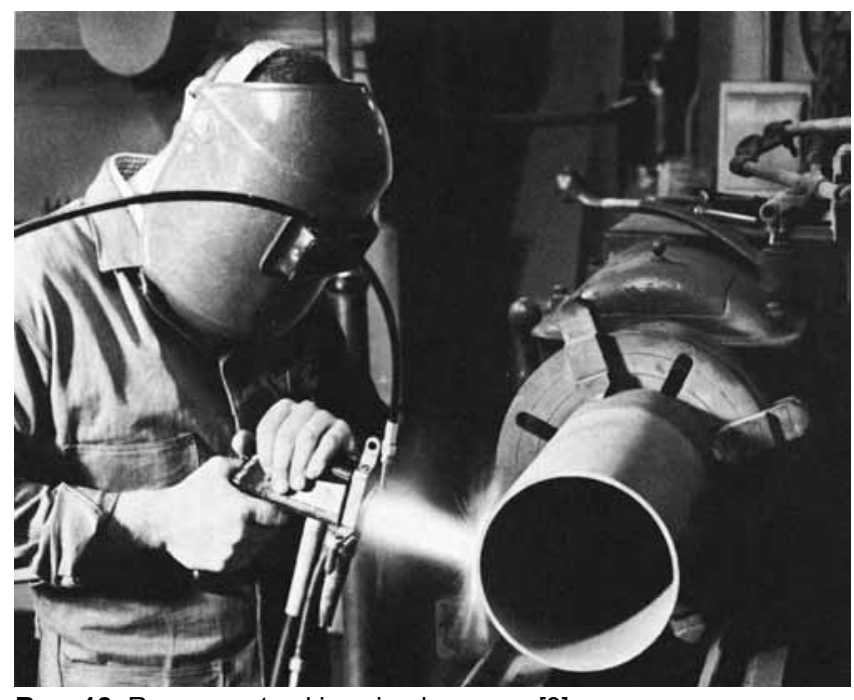

Rys. 18. Ręczne natryskiwanie plazmowe [9]

Fig. 18. Hand held plasma spraying gun [9]

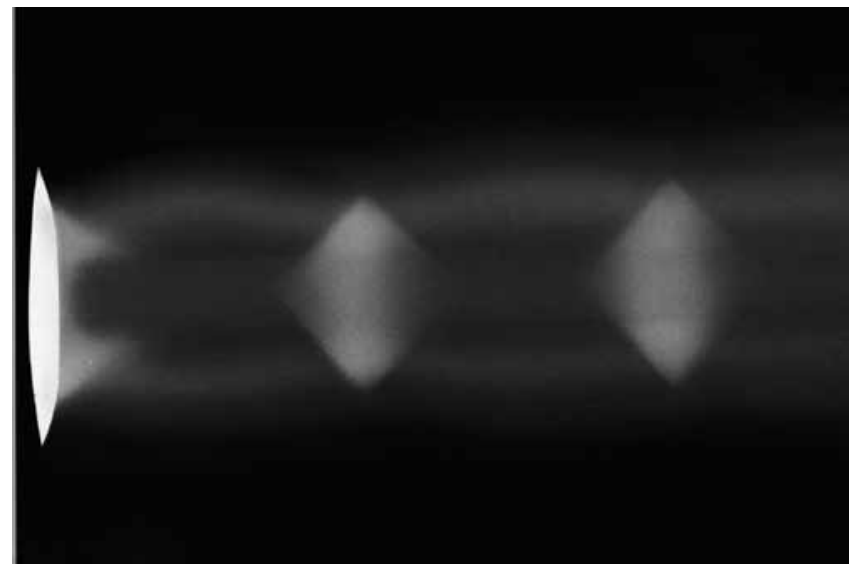

Rys. 20. Charakterystyczne "diamenty” w strumieniu HVOF. Fot. Perkin Elmer

Fig. 20. "Diamonds" - characteristic feature for HVOF spraying. Photo Perkin Elmer

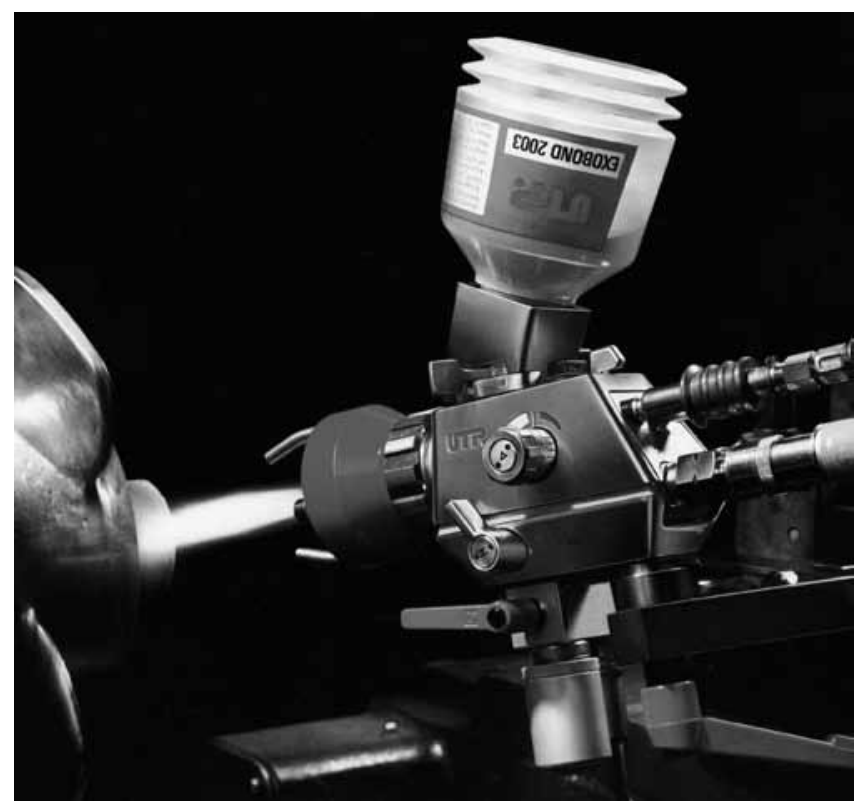

Rys. 21. Pistolet Uni Spray Jet. Fot. UTP

Fig. 21. Uni Spray Jet - the series HVOF gun. Photo UTP

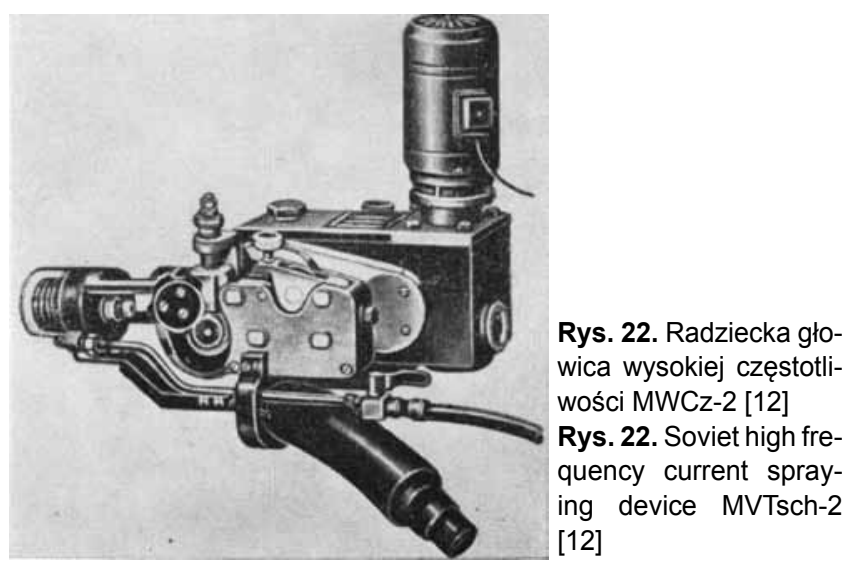

a więc łatwiej, niż przy natryskiwaniu detonacyjnym, uzyskać powłoki o jednorodnej grubości. Generowany hałas jest znacznie mniejszy niż w przypadku urządzeń detonacyjnych, a same głowice są stosunkowo lekkie i poręczne, co umożliwia wykonywanie prac zarówno w trybie zautomatyzowanym, zmechanizowanym, jak i ręcznym. Uzyskiwane prędkości ziaren są nieco mniejsze niż w przypadku D-gun, ale kilkakrotnie większe niż przy natryskiwaniu płomieniowym, co powoduje radykalny wzrost przyczepności warstw oraz rozszerza wachlarz nanoszonych materiałów. Wspólną wadą metod detonacyjnej i HVOF jest niemożność uniknięcia utleniania materiału nanoszonego z powodu konieczności zastosowania w obu procesach gazu palnego i utleniacza.

\section{Inne metody}

W połowie lat 50. ub.w. w ZSRR pod kierunkiem Sawinkowa opracowano głowicę do natryskiwania, w której materiał dodatkowy w postaci drutu był topiony przez prądy wysokiej częstotliwości [27]. Nie zyskał on jednak popularności, choć produkowano seryjnie urządzenia działające na tej zasadzie.

Znacznie efektywniejszym rozwiązaniem okazało się natryskiwanie gazodynamiczne, znane szerzej jako natryskiwanie zimne (cold spraying). Jest to najnowsza, stosowana na szerszą skalę technologia natryskiwania, ale można też przyjąć, że stanowi rozwinięcie idei Thurstona z 1900 r. [2]. Technologia powstała w połowie lat 80. ub.w. w Instytucie Mechaniki Teoretycznej i Stosowanej w Nowosybirsku i została opatentowana w USA w 1990 r. [28]. Jej idea sprowadza się do nanoszenia warstw z wykorzystaniem materiału dodatkowego w postaci proszku, który nie jest w czasie natryskiwania topiony. Gaz transportujący jest podgrzewany do temp. znacznie niższej od temp. topnienia materiału dodatkowego (nieprzekraczającej $800^{\circ} \mathrm{C}$ ), a głównym czynnikiem, warunkującym związanie warstwy z podłożem, jest energia kinetyczna, czyli prędkość ziaren. Strumień gazu jest wydmuchiwany pod ciśnieniem do 40 barów i osiąga prędkość $300 \div 1200 \mathrm{~m} / \mathrm{s}$. 


\section{Podsumowanie}

W odróżnieniu od napawania, które może być prowadzone $z$ użyciem typowego sprzętu spawalniczego, natryskiwanie termiczne wymaga specjalnych urządzeń. Brak przetopienia podłoża podczas natryskiwania powoduje, że składniki warstwy i podłoża nie mieszają się ze sobą, dzięki czemu jest możliwe nanoszenie powłok metalicznych o niemal dowolnym składzie na niemal każdy rodzaj podłoża. Można także nanosić warstwy ceramiczne oraz wykonane z niektórych tworzyw sztucznych. Ogromnie szeroki jest zakres możliwych zastosowań praktycznych, a różnorodność dostępnych technologii pozwala na ich optymalne dostosowanie do konkretnych potrzeb. Technologie te powstawały równolegle $z$ analogicznymi technologiami spawalniczymi: najpierw były to metody płomieniowe, potem łukowe, a wreszcie plazmowe. Najnowsza, jeszcze nie w pełni wykrystalizowana tendencja, to wprowadzenie laserów, jako precyzyjnie działającego źródła ciepła, na początek choćby w procesach hybrydowych.

\section{Literatura}

[1] Schoop M. Verfahren zum Herstellen dichten metallischer Ueberzuege Kaiserliches Patentamt Nr 2585051913.

[2] Thurston S. Method of impacting one metal upon another. US Patent 7067011900.

[3] Gunther H., Schoop M. Das Schoopsche Metalspritzverfahren. Verlag der Technischen Monatshefte. Stuttgart 1917.

[4] Kutscher G. Das Metallspritzen und seine Anwendung. w: Apparatebau 36/1924.

[5] Karg H. Beitrag zur Theorie und Praxis des Metallspritzverfahrens. w: Korrosion und Metallschutz 3/1927.

[6] Reininger H. Wesentliche Merkmale gespritzter Metalluberzeuge. w: Zeitschrift der Metallkunde 25/1933.

[7] Schenk G. Haftvermogen und Dichte gespritzter Metallueberzeuge. w: Werkstattstechnik und Werkleiter 27/1933.

[8] Daeschle C.H., Schoop M.U. Handbuch der Metallspritztechnik. Rascher Cie Verl. Wien 1935.

[9] Ingham H., Shepard A. Flame spray handbook. Vol. III Plasma flame process. Metco Inc. New York 1965.

[10] Abert Ch., Siegmann S. 100 years of thermal spraying: About the inventor Max Ulrich Schoop. w: Surface \& Coatings Technology 220 (2013) 3-13.

[11] Kretzschmar E. Metall- Keramik- und Plastspritzen. VEB Verlag Technik. Berlin 1963.

[12] Milewski W. Elektrometalizacja. WNT Warszawa 1968.

[13] Kalendarz spawalniczy na rok 1935 . Perun sp.akc. Warszawa 1934.

[14] Kowalewski Z. Metalizacja natryskowa. PWT Warszawa 1957.

[15] Poradnik Spawalniczy. WNT Warszawa 1970.

[16] Neininger F. Elektrisches Verfahren und Vorrichtung zum Metallspritzen. Eidgenossische Amt fuer Geistiges Eigentum. Patent $\mathrm{Nr} 800981919$
[17] Schoop M., Seelig C. Aus dem Leben eines Schweizerischen Erfinders - Dr.-Ing. h.c. Max Ulrich Schoop. Verein Gute Schriften. Zuerich 1956.

[18] Korzun M. 1000 słów o materiałach wybuchowych i wybuchu. Wyd. MON Warszawa 1986.

[19] Buckley Ebrey P. The Cambridge Illustrated History of China. Cambridge University Press. Cambridge 1996.

[20] Poorman R., Sargent H. Method and apparatus utilizing detonation waves for spraying and other purposes. US Patent 27145631954.

[21] Zverev A. Installation for detonation working of materials. US Patent 37732591972.

[22] Bondarenko A. Apparatus for detonation applying of coatings. US Patent 40047351974.

[23] Astakhov Ye. Apparatus for coating by detonation waves. US Patent 279383. 1975.

[24] Mikoś M. Plazmotron prądu stałego małej mocy do natryskiwania. Patent PL 13990281 Urząd Patentowy Polskiej Rzeczypospolitej Ludowej. Warszawa 1987.

[25] Smith G., Eschenbach R., Pelton J. Jet plating of high melting point metals. US Patent 28619001958.

[26] Szulc T. Początki napawania utwardzającego. w: Przegląd Spawalnictwa 9/2011.

[27] Wlasov A. Napylenie $s$ ispolzovaniem vysokocastotnogo toka. w: Vestnik Masinostroyenia 4/1958.

[28] Papyrin N., Alkhinov A. Gas-dynamic spraying method for applying a coating. US Patent $53024141990 \mathrm{r}$.

[29] Nadasi E. Nowoczesne metody metalizacji natryskowej. WNT Warszawa 1975.

[30] Meurer'sche A.G. füer Spritzmetallveredelung. Berlin ok. 1925. 